\title{
"POLITICAL AND PSYCHOLOGICAL CULTURE AND ITS RELATIONSHIP TO UNIVERSITY INTEGRATION AMONG STUDENTS OF THE FACULTY OF POLITICAL SCIENCES”
}

\author{
Assistant Prof. Dr. Sufyan Saeb Salman \\ Educational and Psychological Research Center / University of Baghdad e. mail: Al_maddidi@yahoo.com
}

\author{
Assistant Prof. Dr. Natik Fahal Al- Kubaisy \\ Educational and Psychological Research Center / University of Baghdad e. mail: dr.natik @ yahoo.com
}

\author{
Assistant Prof. Dr. Mohamed Abbas Mohamed \\ Educational and Psychological Research Center / University of Baghdad e. mail: algburimohammed@yahoo.com
}

\begin{abstract}
:
Culture is one of the requirements of the daily life of the individual in any society, whether it is advanced or simple, and the concept of culture has many aspects, including what education is a culture and there are those who claim that art is a culture, and there are those who classify it according to human societies. And some go to it. It is not related to study and learning. Iraq was a symbol of Arab culture, but it retreated due to the political and social crises it went through in its modern history, and the current research aims to study political and psychological culture and its relationship to university integration among students of the Faculty of Political Science.
\end{abstract}

Key words:

culture, psychological, university integration, university students

Article Received: 18 October 2020, Revised: 3 November 2020, Accepted: 24 December 2020

\section{INTRODUCTION}

Research problem: University students are among the most important groups that societies need, and upon which the country is built. The university student is a continuous interaction with others and society. Based on this, we have to pay attention to his culture in general and his specialized culture in particular, as culture determines his feelings and emotions towards people and towards his colleagues and also leads to refining the general behavior with his emotions and feelings, and this leads to the building of sound mental health.[Abd al-Sattar, 2011] Building a political and psychological culture requires more attention to the scientifically constructed student, and the student who possesses the culture will be able to properly analyze the scientific information given to him, especially since our research is on students of the Faculty of Political Science that is interested in building politicians in the future and is interested in propositions Intellectual and political sciences alike, which we must take care of teaching them psychological sciences as well, so that the cognitive aspects of their studies of political science are complete. General culture is an ancient term that is as old as human life, and this term is concerned with behavioral and human interaction with others with all their human orientations, beliefs, attitudes and intellectual values, as it is concerned with the scientific information carried by the individual in all directions of encyclopedic knowledge and its moral and social trends. The culture of the nation is like the personality of the individual, just as each individual has his own personality that distinguishes him from other individuals, and so is the nation, as each nation has its own culture and intellectual orientations.[Ali, 2009] Culture, in its general sense, is the ability of the individual to create his own being within society and the ability to adapt within this society and bear the positives and 
negatives of any society in which the human being is present. It is also concerned with what he can be with himself and while he is in a certain group. However, the researcher sees (and he will separate that later) that the individual in our societies faces the contradictions between the nomadism in which a generation is brought up and the human culture that is undergoing a great acceleration that corresponds to What is experienced by the societies of the developed world. The concept of political culture is considered one of the relatively modern concepts in the world of politics, and its emergence did not go back until 1956, when Gabriel Almond used this concept as a dimension from the exclusion of the analysis of the political system, and that every political system, according to what Almond sees, is rooted around limited patterns of trends that control interactions Included in the social system.[Nazem, 2008] And political culture in the current era is one of the most important approaches to political sociology. The Department of International Knowledge for Social Sciences has defined political culture as a set of beliefs and trends that organize and give meaning to the political system and political culture in this sense is part of the general culture of society. It refers to the group of knowledge, political opinions, and trends in politics and governance, loyalty and belonging, legitimacy and participation. [Qais, 2008] As for university integration, it is the process of interacting with colleagues and expressing feelings and emotions. It includes expressing feelings in the manner required by the situation without denying the feelings of others. University education is a new experience for the student to face and live with, and continuous interaction in a sound manner followed by a sound professional choice. (Salah, 2007) The problem of researching these two variables arises among university students. Building political and psychological culture calls for university integration of the student with his colleagues in order to negotiate in solving problems between them.

Research importance: The culture of the most important features of university student so university professor focuses on student building a cultural and scientific focus on his reading of specialization and learning in other disciplines approach, and culture is in the study stage of the basics of building a student university. Also, the subject of university integration is one of the important topics that the student must work on from his first day of university studies, and thus he can build scientific and social communication with his colleagues and professors properly. Studies have confirmed the importance of university integration, as some emphasized that the integration of students at the university is important to their lives and the continuation of education and general culture [Taylor, J, 2015] Psychologist (Eric From The human being is a social being by nature, he must be studied according to his social relations and his integration with people. Social relations are an important part of an individual's life, and his success in his social life depends on his ability to form a correct social integration. University integration is an indication of the mental health of the individual, as he feels good with his relationships, the strength of his relationships, the correct character building, and the optimal development of his concepts.[Ahmed, 2015]

\section{Research aims:}

- Knowing the level of psychological and political culture among university students

- Knowing the level of university integration among university students

- Know the relationship correlation between the culture of political psychological and integration among university students.

\section{Define terms}

Psycho-culture: (Garner) defines it as a life approach taken by individuals within society.[Anthony, 2005] While (Tyler 1977) believes that psychological culture is an emotional behavior that individuals take and inherit from their parents and grandparents by sympathy.[Louis, 1981] Malinovsky believes that psychological culture is a process of great change 
in the reality of society and begins with the individual, so the small community group reaches the reference group that must take what the individual wants from a unified psychological position and the society's culture changes on its basis and its light.[Louis, 1981] Whereas (Abraham) believes that psychological culture is a form of anthropology that is derived from different customs and cultures that together constitute the values and standards adopted in practice in any society in the world and these are the product of different world cultures.[Karl, 1998]

Political culture: Coleman knows it as set of criteria that societies agree upon to determine their relationship to power. Jasim knows it by a number of commonalities that determine a person's knowledge of political law, with what it has and what it is. And the researcher knows it: They are humanitarian standards agreed upon by researchers in political science so that the citizen can take them and learn from them how to deal with political power.

University integration: Marx defined it as a psychological process that includes attention, interest, and the effort that a student puts into learning.[Marks, 2000] Frederick defined it as a psychological process related to arousing attention and investing effort in the learning process and achieving harmony and satisfaction between them and between the university environment with all its components.[Fredrick, 2004]

\section{LITERATURE REVIEW}

Political culture includes various directives on one side and apparent and subconscious behavior on the other hand, for example that it is part of the general culture and one of the basic and sensitive elements in the formation of the general culture.[Qais, 2008] There are several elements of political culture, including the perceptual, the emotional, and the evaluative. Alfred Adler thought that culture is often a reason to compensate for the deficiency of the individual, so he argues that the human personality makes up for a lot of the deficiency in it by increasing the amount of information and obtaining a culture or the accumulation of cultural information for the individual.[Abd al-Rahman, 2009] The psychologist (Maslow) goes to the point that culture is part of the hierarchy of needs that he has set up and begins with physiological needs up to the stage of self-affirmation and self-esteem and what is in between, the individual tries to reach the higher culture after being able to assure his basic needs such as hunger, thirst and sex and others, and to fulfill the need for security and psychological security, to jump from them to other needs, including self-realization and selfaffirmation through the general culture that the individual attains .[Linda, 1983] Karen Horney said that neurosis and mental illness have a great role in building the general culture of any country or group living in that country. As for the viewpoint of social psychology, it goes to the fact that culture and education in society come from the agencies of socialization, previously represented by ((home, school, peers, television, broadcast media such as radio, daily newspapers and magazines, ..... etc.)), and add them unless he thinks former scientists.. What happened to the technological development of international information network (internet) and the means of social communication, which is working on it and do, and mobile phones? and other modern means of communication and information.[Karen, 1987] The researcher believes that all of the above has a major role in establishing and building the scientific, literary, and political culture of the university student as well as the intellectual structure that the university professor bears the bulk of it by providing him with scientific information and preparing it for them and preparing them for the future. And this topic is one of the important topics that should occupy the minds of those interested in basic education and higher education in Iraq, since without the correct establishment of information, we will not find after years our Iraqi student, whom we want the most brilliant intellectual, as his predecessors were. And in university integration, I dealt with the theory of the integration model for Tinton 
Social participation, which focused on the student's social interaction, his colleagues 'participation in social activities, his interaction with colleagues and his professors, and linking them to the strength of the scientific effort that he exerts. The more he was able to master the subject, the more he was able to socialize with the educational environment at the university. While the theory of Frederick and others tended in 2004. To the fact that integration is represented in two directions, the first is positive behavior, such as observing university regulations, and the second is scientific effort and perseverance in class and extracurricular learning, and thus integration is accomplished through the completion of scholastic tasks and adherence to the instructions and the system and This makes the student fruitful, productive, integrated with colleagues and professors with all his might. In the study Judge, he found that new students cannot integrate with the university's atmosphere, and that there is a difference of statistical significance in favor of students of human departments at the expense of scientific departments in Integration University and that there is a positive relationship between university integration and emotional intelligence. [Adnan, 2012]

\section{METHODOLOGY}

Research sample: The research sample was intentionally chosen from students of the third stage at the College of Political Science at the University of Baghdad, as the research variables apply to them accurately. The research sample in its final form consisted of (130) male and female students.

Research tool : The researcher prepared the Political and Psychological Culture Scale, which may be in its final form (35 paragraphs) that were formulated after completing the statistical procedures related to the scale. As the adoption of a measure, the author of (paragraph 36) offset by five alternatives (always apply to, apply to, apply to sometimes, does not apply to, and never apply to). And they were applied to the research sample of 130 students and students from the third stage of the Faculty of Political Sciences at the University of Baghdad.

\section{RESULTS}

1. The level of psychological and political culture among university students.

\begin{tabular}{|l|l|l|l|l|l|l|l|}
\hline $\begin{array}{l}\text { the } \\
\text { samp } \\
\text { le }\end{array}$ & $\begin{array}{l}\text { Arithmet } \\
\text { ic mean }\end{array}$ & $\begin{array}{l}\text { standar } \\
\mathbf{d} \\
\text { deviatio } \\
\mathbf{n}\end{array}$ & $\begin{array}{l}\text { Hypothesiz } \\
\text { ed mean }\end{array}$ & $\begin{array}{l}\text { Degree } \\
\text { of } \\
\text { freedo } \\
\text { m }\end{array}$ & $\begin{array}{l}\text { The } \\
\text { compute } \\
\text { d T- } \\
\text { value }\end{array}$ & $\begin{array}{l}\text { Tabul } \\
\text { ar T } \\
\text { value }\end{array}$ & $\begin{array}{l}\text { Indicati } \\
\text { on level }\end{array}$ \\
\hline 130 & 93.54 & 9.088 & 81 & 129 & 14.25 & 1.96 & 0.05 \\
\hline
\end{tabular}

Table (1)

The result indicated that there is a high level of psychological and political culture among university students, and this is consistent with the reality of the situation and previous studies, that the students of the third stage took a measure of learning that allows them to obtain what was mentioned above, and that the student at this stage is trying to reach a rate of political culture.

\section{The level of university integration of students.}

\begin{tabular}{|l|l|l|l|l|l|l|l|}
\hline $\begin{array}{l}\text { the } \\
\text { samp } \\
\text { le }\end{array}$ & $\begin{array}{l}\text { Arithmet } \\
\text { ic mean }\end{array}$ & $\begin{array}{l}\text { standar } \\
\text { d } \\
\text { deviatio } \\
\text { n }\end{array}$ & $\begin{array}{l}\text { Hypothesiz } \\
\text { ed mean }\end{array}$ & $\begin{array}{l}\text { Degree } \\
\text { of } \\
\text { freedo } \\
\text { m }\end{array}$ & $\begin{array}{l}\text { The } \\
\text { compute } \\
\text { d T- } \\
\text { value }\end{array}$ & $\begin{array}{l}\text { Tabul } \\
\text { ar T- } \\
\text { value }\end{array}$ & $\begin{array}{l}\text { indicati } \\
\text { on }\end{array}$ \\
\hline 130 & 120.11 & 8.29 & 108 & 129 & 16.36 & 1.96 & 0.05 \\
\hline
\end{tabular}


Table (2)

This coincides with the results of studies, as the university student tries to integrate with his colleagues, to relate to his new world, to build good relations scientifically and socially, and to try to reach the scientific and social effort to the highest level.

The third goal: To know the correlation between psychological and political culture and university integration among students.

After analyzing the results using the Pearson correlation coefficient, the researcher found a correlational relationship between psychological and political culture and university integration among students, as the value of the correlation coefficient was $(0.185)$, which is higher than the tabular value of (0.174)

And by using the T-test to know the significance of the correlation coefficient, the calculated $\mathrm{T}$ value $(2,153)$ was higher than the tabular value (1.96) at a significance level of 0.05 and a degree of freedom 129.

This indicates that a student who possesses a general culture or a psychological and political culture can integrate with university life and deal with laws and educational systems with great ease. And this result gives us an indication of the importance of building the ranks of the student to enable him to integrate with his university life better.

\section{RECOMMENDATIONS:}

- Preparing gatherings to celebrate the first stage students, aiming at their integration into the university community.

- Printing educational brochures aimed at teaching university students the importance of general and specialized culture. And distributed to the students of the first stages

- Printing informative brochures of the university rules and regulations and distributing them to students

- Introduce students to the importance of university life.
- Preparation courses for university educational counselors in how to integrate new university student life.

\section{PROPOSALS}

- Conducting a similar study for students of scientific colleges.

- Conducting a similar comparative study between the faculties of science and humanities, looking at culture and university integration

- Preparing weekly meetings for the first stage students with their older colleagues to try to accommodate them in their new scientific life.

- Helping new students to prepare them for university life by the scientific administrations in colleges and universities.

\section{REFERENCES}

[1] Abd al-Sattar Ibrahim, Modern cognitive behavioral and psychological therapy, Egyptian Book Authority, Cairo, 2011, p.13

[2] Ali Al- Wardi, A Study on the Nature of Iraqi Society, Tigris and Euphrates Library House, Beirut, 2009, pp. 52-53

[3] Nazem Al- Jassour, Encyclopedia of Political, Philosophical and International Terms, Dar Al-Nahda Al-Arabiya, Beirut, 2008, p.225

[4] Qais Jabbar Al-Kalabi, Political Culture among Students of Baghdad University, University of Baghdad, College of Political Sciences, Unpublished Master Thesis, 2008, p.6

[5] Salah Al-Din Ahmad Al-Jami', Psychological and Social Alienation and Its Relationship to Psychological Consensus, Madbouly Library, Cairo, 2007, p.18

[6] Taylor, J, \& Nammles School engagement and life chance in 15 years old and transition, Brotherhood of St, Laurence, 
National library of Australia Cataloging, 2006, p, 76

[7] Ahmed Jassim, Public Policies, Dar AlNahda, Cairo, 2015, p.17

[8] Anthony Gerner, Sociology, Translated by: Faiz Al-Sabbagh, Tarjuman Press, Beirut, 2005, p.79

[9] Louis Mir, Introduction to Social Anthropology, translated by: Shaker Mustafa Salim, House of General Cultural Affairs, Baghdad, 1981, p.33

[10] [10] Ibid, p.175

[11] [11] Karl Abraham, Psychoanalysis and Culture, translated by: Wajih Asaad, Publications of the Ministry of Culture, Syrian Arab Republic, 1998, p.193

[12] Marks, H, M., student engagement in instructional activity: patterns in the elementary, middle and high school years, American education research journal, 37 (1), 2000, p 155

[13] Fredrick, J, A, Blue men field, P, C, \& Paris, A, H School Engagement potential of the concept> stste of the evidence, Review of educational research, 17, 2004, p 10

[14] Qais Jabbar Al-Kalabi, Political Culture among Students of the University of Baghdad, University of Baghdad, College of Political Sciences, Unpublished Master Thesis, 2008, p.17

[15] Abd al-Rahman Adas, Introduction to Psychology, Dar Al Fikr, Amman, The Hashemite Kingdom of Jordan, 2009, p.135

[16] Linda, Al Davidoff, Introduction to Psychology, Translated by: Syed Tawab and others, McGar and Hill House, International Publishing and Distribution House, 1983, p.345

[17] Karen Horney, A constructive theory on neurosis, translated by: Ibrahim Al-Sheikh, House of General Cultural Affairs, Baghdad, 1987, p.67

[18] Adnan Muhammad Al-Qadi, Emotional Intelligence and its Relationship to
University Integration among Students of the College of Education at Taiz University, The Arab Journal for the Development of Excellence, Issue 4, Yemen, 2012, pp. 58-60 